\title{
COMPETION AND PRICE
}

ADJUSTMENT IN THE EURO AREA

Luis J Alyarez and gnacio Hernando

Documentos de Trabajo. N. 0629

baneo españa 
COMPETITION AND PRICE ADJUSTMENT IN THE EURO AREA 
COMPETITION AND PRICE ADJUSTMENT IN THE EURO AREA $\left(^{*}\right)$

Luis J. Álvarez and Ignacio Hernando $\left.{ }^{(*}\right)$

BANCO DE ESPAÑA

${ }^{(*)}$ This paper will be published in an Oxford University Press book entitled Pricing Decisions in the Euro Area: How Firms Set Prices and Why, edited by Silvia Fabiani, Claire Loupias, Fernando Martins, and Roberto Sabbatini. We are grateful to all members of the Eurosystem Inflation Persistence Network (IPN) and, particularly, Luc Aucremanne, Josef Baumgartner, Martine Druant, Silvia Fabiani, Angela Gattulli, Marco Hoeberichts, Claudia Kwapil, Bettina Landau, Claire Loupias, Patrick Lünnemann, Fernando Martins, Thomas Mathä, Pedro Neves, Roland Ricart, Roberto Sabbatini, Johann Scharler, Harald Stahl and Ad Stokman for helpful discussions and for providing industry data from their national surveys. We also acknowledge comments from Juan Peñalosa. The views expressed in this paper are those of the authors and do not necessarily reflect the views of the Banco de España.

(*) E-mail: Luis J. Álvarez (ljalv@bde.es). Ignacio Hernando (hernando@bde.es). 
The Working Paper Series seeks to disseminate original research in economics and finance. All papers have been anonymously refereed. By publishing these papers, the Banco de España aims to contribute to economic analysis and, in particular, to knowledge of the Spanish economy and its international environment.

The opinions and analyses in the Working Paper Series are the responsibility of the authors and, therefore, do not necessarily coincide with those of the Banco de España or the Eurosystem.

The Banco de España disseminates its main reports and most of its publications via the INTERNET at the following website: http://www.bde.es.

Reproduction for educational and non-commercial purposes is permitted provided that the source is acknowledged.

\section{(c) BANCO DE ESPAÑA, Madrid, 2006}

ISSN: 0213-2710 (print)

ISSN: 1579-8666 (on line)

Depósito legal: M. 45470-2006

Imprenta del Banco de España 


\begin{abstract}
This paper explores the role of a number of factors in explaining the heterogeneity in the degree of price stickiness across industries, on the basis of the information provided by surveys on pricing behavior conducted in nine euro area countries. The main focus is placed on the influence of competition on the degree of price flexibility. Our results suggest that the price setting strategies of the most competitive firms give them a greater capacity to react to shocks and make, in practice, for greater flexibility in their prices. The direct influence of market competition on price flexibility is corroborated by a cross-country cross-industry econometric analysis based on the information provided by surveys. This analysis also shows that the cost structure and demand conditions help to explain the degree of price flexibility. Finally, it suggests that countries in which product market regulation is more relevant are characterized by less price flexibility.
\end{abstract}

Keywords: price setting, competition, survey data.

JEL Codes: D40, E31. 


\section{Introduction}

A crucial factor determining firms' pricing behavior is the degree of market competition. Since early studies on price stickiness using micro data, the relationship between market structure and pricing behavior has been a highly researched issue in industrial economics. ${ }^{1}$ In particular, a great deal of attention has been devoted to the question of whether firms in competitive markets are more likely to change prices in response to shocks than firms enjoying significant market power [see for instance Ginsburgh and Michel (1988) and Martin (1993)]. Moreover, firms in more competitive industries, facing higher uncertainty about their future position in the market, may be more concerned with ensuring short-run returns, which leads to a higher responsiveness to current shocks [Encaoua and Geroski (1986)]. By contrast, firms facing less competition can place more emphasis on long-term returns and adopt pricing policies that smooth out expected fluctuations in costs and demand. ${ }^{2}$ Oligopolists may prefer delays in adjusting prices in order to avoid breaking tacit pricing understandings [Stiglitz (1984)].

There are also a number of empirical papers linking price stickiness and degree of market competition. For instance, Carlton (1986) and Hall et al. (2000) find that firms in competitive markets tend to adjust prices faster than companies facing a less elastic demand. Geroski (1992) shows that price responses to both supply and demand shocks are faster in more competitive industries. Similarly, Weiss (1995) finds that cost changes are more fully transmitted into prices in industries with low concentration ratios. Overall, the empirical evidence tends to favor the existence of a positive link between price flexibility and the degree of competition [see Dixon (1983); Encaoua and Geroski (1986), and Bedrossian and Moschos (1988)], although there are also studies reporting the opposite result. For instance, Domberger (1979) finds a positive relationship between the speed of price adjustment and market concentration. He rationalizes this result by arguing that prices should react faster to costs shocks in concentrated industries, given that information is more easily gathered the higher the degree of concentration. ${ }^{3}$

More recently, renewed attention has been placed on the empirical relevance of the relationship between the degree of price stickiness and the intensity of market competition. For instance, the existence of a positive association between the frequency of price change and the degree of competition has been documented on the basis of individual producer prices for Spain and Belgium [see Álvarez et al. (2005) and Cornille and Dossche (2006), respectively] and for Luxembourg using consumer prices [Lünnemann and Mathä (2005)]. Furthermore, the qualitative information in the surveys on price setting behavior discussed in this book has provided an alternative source to assess the empirical significance of this relationship, which has been analyzed in several countries (see section 3 below).

1. See Mills (1927) and Means (1936) for early contributions on the behavior of individual prices, and Silberston (1970) and Carlton (1989) for surveys of theoretical and empirical work on the relationship between pricing behavior and market structure.

2. A similar argument is considered by Eichner (1973). Industries characterized by increasing returns to scale usually lead to a small number of competitors that carry out the necessary large irreversible investments. The pricing policies of these firms are more oriented by long-run objectives than by short-run costs or demand fluctuations.

3. This argument is consistent with Stigler's (1964) model, according to which the fewer the number of firms in an industry the easier it is to monitor price cuts. Identifying price cuts with slow adjustment to cost increases, it can be argued that the fewer the number of firms, the faster the adjustment to cost shocks. 
In this paper, we analyze the relationship between price flexibility and competition, focusing on euro area manufacturing and services industries. The distinguishing features of our study are the consideration of the whole euro area, the use of survey data and the inclusion of services sectors, which are generally neglected in this type of analysis. After this introduction, the structure of the remainder of this paper is the following: section 2 discusses the measurement of the degree of market competition in surveys. Section 3 explores the main features of firms pricing strategies according to their competitive environment. Section 4 shows some evidence on the relationship between competition and the degree of price flexibility. Our econometric results on the determinants of price flexibility in the euro area and presented in section 5 , while section 6 concludes. 


\section{Measuring the degree of market competition}

Measuring the degree of market competition is an extremely complex task that has received a lot of attention in the literature on industrial organization [see, for instance, Bresnahan (1989)]. In the context of the surveys on price setting discussed in this book, most national questionnaires included two questions directly related to the degree of competition faced by firms. Specifically, companies were asked to report on their market share and on the number of competitors. Unfortunately, these two measures have considerable shortcomings. First, both are highly subjective in the sense that different firms may use different criteria to define relevant markets or to identify their potential competitors. Second, in some oligopolistic markets with a small number of big companies enjoying large market shares, there is a very high degree of competition (e.g. telecommunications). Third, some industries may have a large number of competitors, but still maintain local market power (e.g. bars and restaurants).

For this reason, we infer the degree of competition faced by a firm from the importance it attaches to changes in competitors' prices in explaining its own price decreases. The rationale for this choice is that it can be expected that the more competitive is the environment faced by a firm, the more its pricing strategy is likely to be affected by the behavior of its competitors. Interestingly, the Dutch survey [Hoeberichts and Stokman (2006)], which is the only one including a direct question on the degree of perceived competition, comes in with results that support the use of this measure to proxy market competition. The importance attached by firms to changes in competitors' prices turns out to be highly correlated with the directly reported degree of perceived competition. This measure has the additional advantage that it is available for all countries. An additional measure that we use in the empirical analysis is the share of firms that set prices using a markup rule. We expect this share to be negatively related to the degree of market competition. Unfortunately, this information is not available for Austria and Luxembourg.

If we measure intense competition by considering those firms that report that competitors' prices are important or very important in determining a reduction in their own prices, it turns out that around $60 \%$ of firms in the euro area face intense competition (see Table 1). This share ranges from $54 \%$ in Spain to $71 \%$ in the Netherlands, although it has to be borne in mind that these cross-country differences are affected by differences in the sectoral coverage of national surveys. ${ }^{4}$

4. For instance, the degree of perceived competition in Spain is found to be lowest in energy (31\%), energy trade (38\%), and bars and restaurants (44\%). At the other end of the spectrum, the share of firms facing intense competitive pressures is highest in communications (69\%), hotels and travel agents (66\%) and food trade (65\%). 
TABLE 1

Degree of perceived competition ${ }^{a}$ (percentages $^{b}$ )

\begin{tabular}{lcccc}
\hline Country & Very low & Low & High & Very high \\
\hline Austria & 20.2 & 18.2 & 30.3 & 31.3 \\
Belgium & 17.6 & 21.8 & 30.4 & 30.1 \\
France & 19.5 & 17.3 & 38.4 & 24.9 \\
Germany & 19.0 & 23.4 & 34.0 & 23.6 \\
Italy & 9.8 & 24.6 & 37.0 & 28.5 \\
Luxembourg & 15.3 & 17.2 & 36.7 & 30.7 \\
The Netherlands & 4.6 & 24.6 & 48.8 & 22.0 \\
Portugal & 8.5 & 21.1 & 38.6 & 31.9 \\
Spain & 26.6 & 19.2 & 24.0 & 30.2 \\
Euro Area & 17.1 & 21.5 & 35.2 & 26.2 \\
\hline
\end{tabular}

Source: authors' calculations based on national data.

a Measured by the importance a firm attaches to competitors' prices when considering reducing its own prices.

${ }^{\mathrm{b}}$ Rescaled figures excluding non responses.

${ }^{c}$ Weighted average (GDP weights). 


\section{Competition and firms' price setting strategies}

As discussed in the introduction, the degree of market competition is an important factor in determining price setting behavior. In particular, it is reasonable to expect that firms facing a higher degree of competition will employ more flexible price determination strategies, which give them a greater ability to react to changes in market conditions.

In this section we use the results of the national surveys to analyze differences in firms' price setting policies, according to the intensity of market competition. Specifically, we focus on the differences in some aspects of pricing strategies, such as the use of markup rules versus other policies, time versus state dependence, forward looking behavior, and frequency of price reviews, in terms of the degree of competition faced by firms.

The various questionnaires address the issue of how firms set prices using slightly different formulations. Nevertheless, the results of the national surveys, with the exception of those for Austria and Luxembourg, can be compared by grouping the answers into three alternatives: "markup over costs", "price set according to competitors' prices" and "other" [see Fabiani et al. (2006)]. Overall, the evidence, summarized in Table 2, shows that a significant share of firms (54\%) set their prices as a markup over marginal costs, suggesting that they enjoy a non-negligible degree of market power. The fraction of companies setting prices according to those of their competitors is $27 \%$. Finally, around $19 \%$ of the companies state that they do not have autonomous price setting policies. For these firms, the final decision on the price charged is taken by a different economic agent, and this may be the public sector, the parent company, the main customers or the suppliers. 
TABLE 2

Price setting policies by degree of perceived competition ${ }^{a}$ (percentages $^{b}$ )

\begin{tabular}{|c|c|c|c|}
\hline Country & Markup & $\begin{array}{l}\text { Competitors' } \\
\text { price }\end{array}$ & Other \\
\hline \multicolumn{4}{|l|}{ Belgium } \\
\hline All firms & 45.9 & 36.4 & 17.7 \\
\hline Low competition & - & - & - \\
\hline High competition & - & - & - \\
\hline \multicolumn{4}{|l|}{ France } \\
\hline All firms & 40.0 & 38.0 & 22.0 \\
\hline Low competition & 49.8 & 24.4 & 25.9 \\
\hline High competition & 36.0 & 47.6 & 16.4 \\
\hline \multicolumn{4}{|l|}{ Germany } \\
\hline All firms & 73.0 & 17.0 & 10.0 \\
\hline Low competition & 78.9 & 9.4 & 11.7 \\
\hline High competition & 69.8 & 22.5 & 7.6 \\
\hline \multicolumn{4}{|l|}{ Italy } \\
\hline All firms & 42.4 & 31.7 & 25.9 \\
\hline Low competition & 57.6 & 14.5 & 27.9 \\
\hline High competition & 33.6 & 42.6 & 23.7 \\
\hline \multicolumn{4}{|l|}{ The Netherlands } \\
\hline All firms & 56.4 & 22.3 & 21.3 \\
\hline Low competition & 56.6 & 15.3 & 28.2 \\
\hline High competition & 56.5 & 25.4 & 18.1 \\
\hline \multicolumn{4}{|l|}{ Portugal } \\
\hline All firms & 64.5 & 12.6 & 22.9 \\
\hline Low competition & 78.7 & 2.9 & 18.4 \\
\hline High competition & 59.9 & 17.6 & 22.4 \\
\hline \multicolumn{4}{|l|}{ Spain } \\
\hline All firms & 51.9 & 26.6 & 21.5 \\
\hline Low competition & 61.3 & 11.8 & 27.0 \\
\hline High competition & 44.1 & 40.5 & 15.3 \\
\hline \multicolumn{4}{|l|}{ Euro Area ${ }^{c}$} \\
\hline All firms & 54.3 & 27.1 & 18.7 \\
\hline Low competition & 63.6 & 14.7 & 21.7 \\
\hline High competition & 49.8 & 35.1 & 15.1 \\
\hline
\end{tabular}

Source: authors' calculations based on national data.

a Measured by the importance a firm attaches to competitors' prices when considering reducing its own prices.

${ }^{b}$ Rescaled figures excluding non responses.

${ }^{c}$ Weighted average (GDP weights). 
There are interesting differences in these figures with respect to the degree of perceived competition. In particular, we find that the fraction of firms using markup rules is higher among those operating in low competition environments: $64 \%$ as compared to $50 \%$ among firms facing intense competition. This result is qualitatively similar for all countries. In turn, only $15 \%$ of euro area firms operating in low competitive markets set prices taking into account competitors' prices, whereas 35\% of them do so if they face strong competition. This pattern of results also holds for all countries.

State dependent rules may lead to more flexible prices than time dependent ones in the face of shocks; hence, we check whether pure state dependent rules are more frequent among competitive firms. The evidence in favour of this hypothesis is rather weak: the fraction of euro area firms using pure state dependent rules is $27 \%$ among firms facing intense competition and $25 \%$ for firms operating in low competition environments.

The use of forward looking strategies can also be expected to be more widespread in competitive environments. Evidence for Spain shows that price revisions among highly competitive firms do not usually involve the application of simple rules, but are the result of an optimizing process in which expectations as to how market conditions may change are, fairly frequently, taken into account. The fraction of forward looking price setters is 37\% among firms operating in a competitive environment and $18 \%$ for companies facing low competition. Furthermore, the Spanish survey also shows that firms operating in competitive environments use active commercial policies to a greater extent.

There are also differences concerning the frequency of price reviews. As expected, firms operating in more competitive environments review their prices more frequently (Figure 1). For the euro area as a whole, the fraction of firms reporting that competitors' prices are unimportant (very important) and reviewing prices at least twelve times per year is $23 \%$ (34\%). Conversely, the share of companies reviewing prices at most three times per year is $68 \%$ (45\%) for firms reporting that competitors' prices are unimportant (very important) on their pricing decisions. This positive relationship between the frequency of price reviews and the intensity of competition is observed in all countries.

\section{FIGURE 1}

\section{Frequency of price reviews by degree of perceived competition ${ }^{a}$}

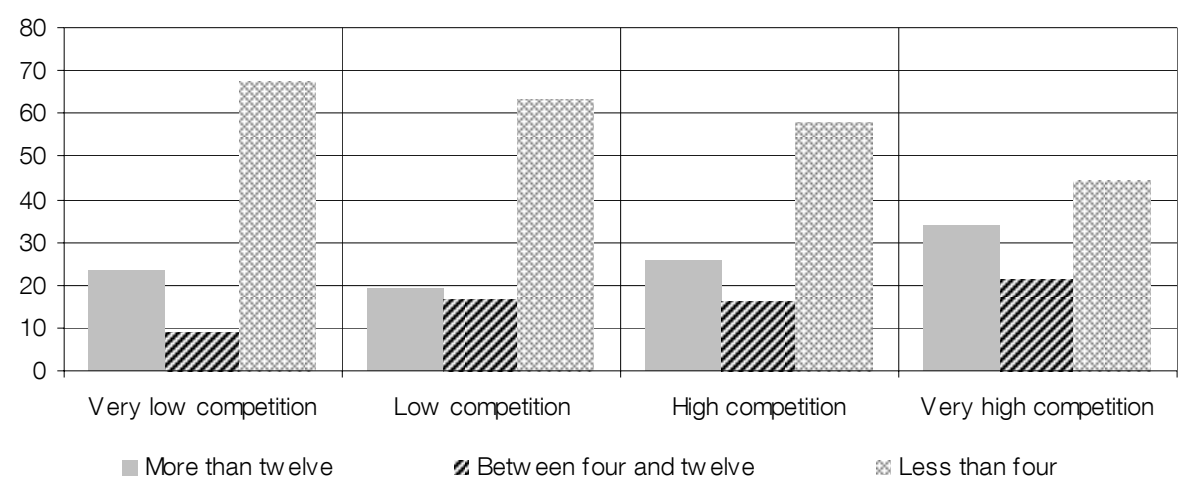

Source: authors' calculations based on national data.

a Measured by the importance a firm attaches to competitors' prices when considering reducing its own prices. 


\subsection{Descriptive statistics}

A first approach to explore the relationship between competition and price stickiness consists in measuring the frequency of price adjustment for different groups of firms defined in terms of the degree of competition they face. As Figure 2 shows, firms facing stronger competitive pressures display a higher frequency of price adjustment. For the euro area as a whole, the share of companies changing prices at least four times a year is 10\% (26\%) for firms reporting that competitors' prices are unimportant (very important) in their pricing decisions. Conversely, the fraction of firms changing prices at most once a year is $73 \%$ (50\%) for firms indicating that competitors' prices are unimportant (very important) in price setting. This pattern of results is observed in all countries with the exception of Austria.

Table 3 reports the average implicit duration as obtained from interval grouped figures for the frequency of price changes for the different countries and degrees of competition. ${ }^{5}$ For the euro area, prices remain unchanged on average for the most competitive firms for 9 months, while in more sheltered markets prices are maintained for 14 months. As can be seen from the Table, the relationship between the degree of perceived competition and the average price duration is negative and monotonic in most countries.

\section{FIGURE 2}

Frequency of price changes by degree of perceived competition ${ }^{a}$

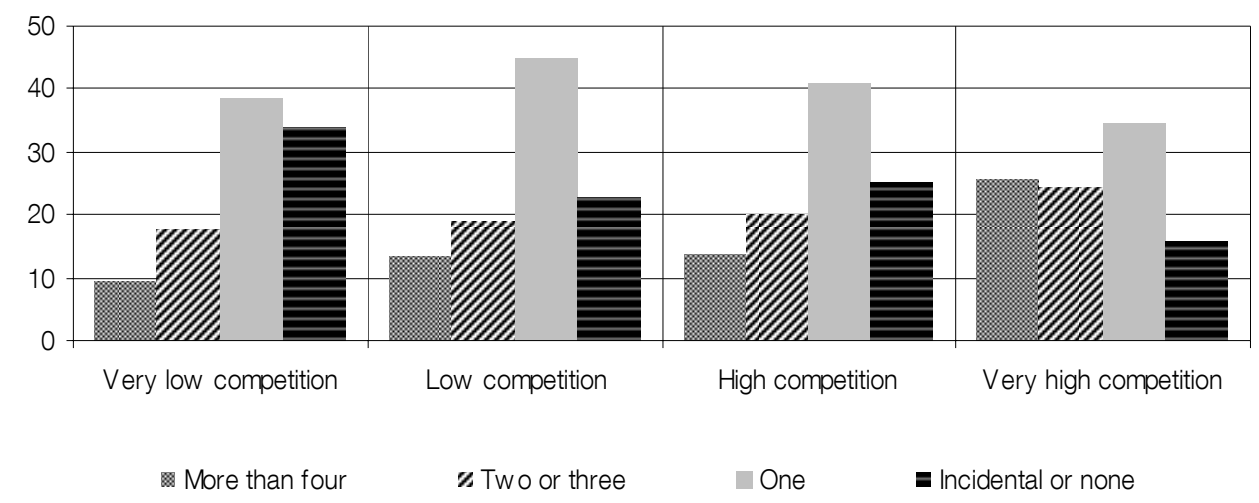

Source: authors' calculations based on national data.

a Measured by the importance a firm attaches to competitors' prices when considering reducing its own prices.

5. To obtain these implicit durations, the following assumptions have been made: for firms declaring "at least four price changes per year" a duration of 1.33 months (i.e. 8 price changes per year) has been considered; for those declaring "two or three changes per year" a duration of 4.8 months (i.e. 2.5 price changes per year); for those declaring "one change per year" a duration of 12 months; and, finally, for those declaring "less than one price change per year", a duration of 24 months. 
TABLE 3

Average implicit price duration (in months ${ }^{\text {a }}$ ) by degree of perceived competition

\begin{tabular}{|c|c|c|c|c|}
\hline \multirow[t]{2}{*}{ Country } & \multicolumn{4}{|c|}{ Degree of perceived competition ${ }^{b}$} \\
\hline & Very low & Low & High & Very high \\
\hline Austria & 10.0 & 9.4 & 9.9 & 10.5 \\
\hline Belgium & 12.7 & 11.9 & 12.0 & 10.8 \\
\hline France & 14.0 & 11.7 & 11.3 & 7.9 \\
\hline Germany & 15.9 & 12.2 & 14.1 & 11.4 \\
\hline Italy & 12.7 & 13.1 & 11.8 & 7.6 \\
\hline Luxembourg & 10.5 & 9.3 & 9.1 & 6.4 \\
\hline The Netherlands & 10.6 & 11.9 & 10.5 & 9.2 \\
\hline Portugal & 13.3 & 13.0 & 12.2 & 11.6 \\
\hline Spain & 13.1 & 11.3 & 11.0 & 9.4 \\
\hline Euro Areac & 13.8 & 12.0 & 12.1 & 9.4 \\
\hline
\end{tabular}

Source: authors' calculations based on national data.

a To obtain these implicit durations, the following assumptions have been made: for firms declaring "at least four price changes per year" it has been assumed a duration of 1.33 months (i.e., 8 price changes per year); for those declaring "two or three changes per year" a duration of 4.8 months (i.e., 2.5 price changes per year) has been considered; for those declaring "one change per year" a duration of 12 months has been considered; and, finally, for those declaring "less than one price change per year", a duration of 24 months has been assumed.

b Measured by the importance a firm attaches to competitors' prices when considering reducing its own prices.

c Weighted average (GDP weights). 


\subsection{Country specific results}

The link between the prevailing competitive environment and the degree of price flexibility has been explored in the different country specific studies, using a variety of methodological approaches. Some studies have analyzed the influence of the degree of market competition on the reported frequency of price changes. In particular, Hoeberichts and Stokman (2006). find a positive impact from the perceived degree of competition on the frequency of price adjustment, using an ordered logit model. In a similar vein, Álvarez and Hernando (2005) report a positive effect of the intensity of competition on the frequency of price changes, in a log linear regression model. In both cases, the estimated models control for other potential determinants of price flexibility. In turn, Aucremanne and Druant (2005) in a bivariate analysis finds that flexible firms -i.e. firms with shorter average duration between two consecutive price changes- tend to experience more competition, as proxied by different indicators such as the number of competitors or the importance of competitors' prices to explain price changes.

The influence of the intensity of competition on the probability of price adjustments after shocks has been addressed for a larger number of countries using probit models. The reaction to positive and negative demand as well as costs shocks has been considered. The general conclusion that arises from these country specific studies is that the speed of response to demand shocks is significantly higher for those firms operating in more competitive environments. In this type of analysis, the dependent variable is a binary variable that is set to 1 if the firm declares that it changes its price (within a specific period or without any time constraint) after the shock and 0 otherwise. In turn, the intensity of competition is proxied by the importance attached by companies to their competitors' prices, although there are country specific differences as well. ${ }^{6}$ Table 4 reports the sign of the estimated impact in the available country studies. Overall, results show that prices are more flexible in response to demand shocks the higher the degree of market competition. This finding holds across countries and independently of the direction of the shocks, although it is not significant for Portugal and, in the case of contractionary shocks, for Spain. These results suggest that a slow price reaction to demand contraction in a highly competitive sector may result in a substantial loss of market share. In contrast, the speed of adjustment to costs shocks does not seem to be significantly affected by the degree of competition.

6. The precise definitions used in the different countries both for the binary dependent variable and for the proxies of competition can be found in the country specific studies. 
TABLE 4

Impact of market competition on the probability of adjustment after shocks (main results from probit analysis) ${ }^{\mathrm{a}, \mathrm{b}}$

\begin{tabular}{|c|c|c|c|c|}
\hline \multirow[t]{2}{*}{ Country } & \multicolumn{4}{|c|}{ Type of shock } \\
\hline & $\begin{array}{l}\text { Increase in } \\
\text { demand }\end{array}$ & $\begin{array}{l}\text { Fall in } \\
\text { demand }\end{array}$ & $\begin{array}{l}\text { Increase } \\
\text { in costs }\end{array}$ & $\begin{array}{l}\text { Fall in } \\
\text { costs }\end{array}$ \\
\hline Austria & + & + & no & no \\
\hline France & + & + & + & no \\
\hline Italy & + & + & - & - \\
\hline Portugal & no & no & no & no \\
\hline Spain & + & no & no & no \\
\hline
\end{tabular}

Source: authors' calculations based on national data.

a " + " denotes that competition is positively and significantly related to the probability of a price increase/decrease in response to an increase/decrease in demand/costs; "-" denotes that competition is negatively and significantly related to the probability of a price increase/decrease in response to an increase/decrease in demand/costs; "no" denotes that competition is not significantly related to the probability of a price increase/decrease in response to an increase/decrease in demand/costs.

b The definition of the dependent variable in the probit analysis as well as of the competition variable may be found in the country specific studies. 
In this section, we explore the potential role of a number of factors to explain differences in the degree of price flexibility across euro area industries. We focus on the competitive environment, the cost structure of the different industries, demand conditions and product market regulations.

\subsection{Data}

We have put together a database using sectoral information from national surveys. Our starting point is the consideration of all NACE 2 digit sectors, where we can broadly distinguish three groups of industries in terms of national coverage. ${ }^{7}$ First, manufacturing, which is covered in all country surveys; second, some market services (trade, hotels and restaurants, and transport and communications), which are covered in at least two big and two small euro area countries; ; and third, the remaining sectors. Our full sample does not include this last group of sectors, since coverage in terms of countries is too limited to be considered informative for a euro area analysis. ${ }^{9}$

There are specific industries in some countries in which only a limited number of firms were surveyed. To ensure that our results are not driven by these observations, we also consider restricted samples made up of those sectors in which there are at least ten surveyed firms in a given country. ${ }^{10}$ We refer to these samples as high representativity samples.

The variables considered in our econometric models are mostly derived from the country surveys. That way the different variables refer to the same set of firms. To enhance the degree of comparability across countries, we employ the same definitions of variables as in Fabiani et al (2006). The main variables we use are the following:

Price flexibility - For the full set of countries, we have information on the number of price changes per year. ${ }^{11}$ Specifically, for each country and industry we know the fractions of firms that change prices considering four different categories: 1) at least four price changes per year; 2) two or three price changes per year; 3) one price change per year; and 4) less than one price change. We use the fraction of firms that change prices at least four times a year as the dependent variable in the econometric analysis.

Perceived competition-One measure of competition is obtained from the importance firms attribute to competitors' prices in influencing a reduction in their own prices. Information refers to a mean score of the following categories: "1=unimportant", " $2=$ of minor importance", "3=important" and "4=very important".

7. Available data for the Netherlands correspond to the aggregate of manufacturing and 5 different services groupings. For Belgium, we have information on 17 aggregates that group NACE sectors.

8. These industries are covered in the Italian and Spanish surveys.

9. Specifically, we cover the NACE 2-digit sectors coded 15, 17-22, 24-36, 51-60, 64. The remaining sectors do not satisfy the two big countries and two small countries minimum coverage rule. The exclusion of the sector "Coke and refined petroleum" is due to its markedly different pricing behavior.

10. Given its special characteristics we have not applied the ten firms minimum for the sector "Office machinery and computers" (NACE 30).

11. Specifically, five national surveys (for Belgium, Spain, Luxembourg, the Netherlands and Austria) refer to the average number of price changes per year in recent years, whereas three (for Italy, France and Portugal) refer to the number of price changes in a precise year. For Germany, the figures we use refer to the number of price changes, as reported by the same firms in the IFO business survey in 2003, given that the German questionnaire did not include a question on the number of price changes. 
Markup - An alternative measure of competition for all countries, except Austria and Luxembourg, can be obtained from questions on price setting. In particular, we use the percentage of firms that declare employing markup over costs rules.

Labor costs, raw materials costs and demand-All national surveys included questions about the factors that are important for changing prices upwards or downwards, including labor costs, raw material costs and demand conditions. Respondents were asked to assign scores between " $1=$ completely unimportant" and " $4=$ very important" to each of them. In our analysis we consider, for each factor, the sum of scores for price increases and decreases.

Product market regulation - We employ both objective and subjective measures of regulation. ${ }^{12}$ For the former, which involve coding a variety of features of different laws and combining them into a single index, we use the estimates provided by Nicoletti et al. (1999). For the subjective measures, which involve coding responses to public opinion surveys of experts or of business people in which respondents are asked about the existence and impact of various regulations, we use the estimates by Pryor (2002). In both cases, measures refer to regulations at the national level, as information at the industry level is not available.

Sectoral dummies - We also consider dummies for groupings of manufacturing sectors (food, other consumer goods, intermediate products, and capital goods) and services sectors (trade, hotels and restaurants, and transport and communications).

\subsection{Econometric methodology}

In our analysis, we model the fraction of firms (freq) that change prices frequently. Given that fractions are bounded between 0 and 1 and linear predictors can take any real value, linear models are inappropriate in this setting and the alternative of using a log-odds ratio model also has potential problems. First, the method is not valid if the fraction takes on the values 0 or 1 , as it is sometimes the case in our sample. Second, further assumptions are needed to recover the conditional expectation. To avoid these problems we use the quasi-maximum likelihood (QML) approach of Papke and Woolridge (1996), involving the estimation of a nonlinear model. Specifically, the observed frequency is expressed as a bounded nonlinear function (typically a cumulative distribution function) of explanatory variables ( $x$ ), and a Bernoulli likelihood function is maximized. The corresponding estimator is consistent and asymptotically normal. In our estimates we use a logistic cumulative distribution function. ${ }^{13}$ That is, we estimate

$$
\text { freq }=\frac{e^{\alpha+\sum \beta_{i} x_{i}}}{1+e^{\alpha+\sum \beta_{i} x_{i}}}
$$

$$
\text { freq Bernoulli }
$$

\subsection{Results}

In this section first we report the results for basic specifications in which we measure the degree of market competition by the importance attached by firms to competitors' prices in explaining their own price cuts and do not include any product market regulation variable. Second, we alternatively proxy competition by the variable markup. Finally, we estimate specifications including product market regulation variables. Throughout we present

12. See Nicoletti and Pryor (2006) for a comparative study of several quantitative indicators of regulation in OECD nations.

13. In our robustness analyses we have also considered a standard normal cdf and a cloglog. Results are not affected by the specific function used. 
results for the full sample of manufacturing and services and also for manufacturing sectors only, since these data refer to all countries. In all cases, we check for robustness using high representativity samples, where only those industries in which at least ten firms are surveyed in a given country are considered.

The first column in Table 5 reports estimates for the complete set of manufacturing and services industries. As can be seen, price flexibility-as measured by the fraction of firms that change prices at least four times a year -is significantly and positively affected by the degree of market competition. Regarding the variables proxying the cost structure, we expect that those sectors where labor costs are highly relevant tend to contain a relatively small fraction of firms that change prices often. This is explained by the fact that wage changes typically take place once a year. On the other hand, those sectors where raw materials are highly relevant can be expected to show a high degree of price flexibility, since raw material prices change very often. In this specification, we estimate a negative coefficient on labor and a positive one on raw materials, although they are not significant. We also find a positive and significant effect of the demand variable, showing that in those sectors where demand conditions are important there is a high degree of price flexibility. Regarding country dummies, we find positive and significant coefficients for Austria, Germany and Luxembourg. This is interesting since Austria and Germany are two countries where product market regulation is low. ${ }^{14}$ Finally, the transport and communications sector is found to be significantly less flexible than the other sectors. ${ }^{15}$ The second column in Table 5 restricts the sample to highly representative industries. The only difference with respect to the whole sample is that cost variables are now highly significant, although the demand variable is no longer significant. Considering only manufacturing industries (column 3), competition, cost structure and demand variables are all significant, with the exception of the labor variable, which is only correctly signed. Finally, restricting the manufacturing sample to highly representative sectors, we find that competition and cost variables are highly significant, although this is no longer the case for the demand variable.

14. No information for Luxembourg is available.

15. According to the results from country specific studies (see, for instance, Álvarez and Hernando (2005), this result is most likely driven by the high stickiness of pricing policies of transport firms. 
Determinants of price flexibility ${ }^{a, b}$ (perceived competition specifications)

\begin{tabular}{|c|c|c|c|c|}
\hline \multirow[t]{2}{*}{ Explanatory variables ${ }^{\circ}$} & \multicolumn{2}{|c|}{ Manufacturing and services } & \multicolumn{2}{|c|}{ Manufacturing } \\
\hline & Full sample & $\begin{array}{l}\text { High } \\
\text { representativity } \\
\text { sample }\end{array}$ & Full sample & $\begin{array}{l}\text { High } \\
\text { representativity } \\
\text { sample }\end{array}$ \\
\hline Perceived competition & $0.69^{* \star}$ & $0.88^{\star \star \star}$ & $0.85^{\star \star}$ & $0.91^{\star \star \star}$ \\
\hline Labor & -0.11 & $-0.56^{\star \star \star}$ & -0.18 & $-0.59^{\star \star \star}$ \\
\hline Raw materials & 0.22 & $0.27^{\star \star}$ & $0.30^{*}$ & $0.32^{\star \star}$ \\
\hline Demand & $0.35^{\star}$ & 0.25 & $0.34^{*}$ & 0.24 \\
\hline Austria & $2.75^{\star \star \star}$ & $2.61^{\star \star \star}$ & $3.06^{\star \star \star}$ & $2.76^{\star \star \star}$ \\
\hline Belgium & 0.23 & -0.1 & 0.54 & 0.13 \\
\hline France & 0.54 & -0.39 & 0.58 & -0.4 \\
\hline Germany & $1.52^{\star \star \star}$ & $0.70^{\star \star}$ & $1.55^{\star \star \star}$ & $0.67^{\star \star}$ \\
\hline Italy & 0.53 & 0.45 & 0.56 & 0.37 \\
\hline Luxembourg $^{d}$ & $1.07^{\star *}$ & $1.57^{\star \star \star}$ & 0.99 & - \\
\hline The Netherlands & 0.64 & 0.43 & - & - \\
\hline Spain & 0.45 & -0.16 & 0.4 & -0.3 \\
\hline Consumer non food goods & -0.47 & -0.2 & -0.45 & -0.19 \\
\hline Intermediate goods & -0.17 & -0.21 & -0.19 & -0.22 \\
\hline Capital goods & -0.56 & -0.38 & -0.55 & -0.39 \\
\hline Trade & 0.66 & 0.28 & - & - \\
\hline Hotels and restaurants & -0.32 & -0.25 & - & - \\
\hline Transport and communications & $-1.08^{\star \star}$ & $-1.18^{\star \star \star}$ & - & - \\
\hline Constant & $-6.68^{\star \star \star}$ & $-4.38^{\star \star \star}$ & $-7.26^{\star \star \star}$ & $-4.53^{\star \star \star}$ \\
\hline Number of obs. & 162 & 133 & 137 & 113 \\
\hline Pseudo R squared & 0.48 & 0.40 & 0.47 & 0.41 \\
\hline Log likelihood & -49.61 & -39.78 & -42.19 & -33.83 \\
\hline $\mathrm{AlC}$ & 137.22 & 117.56 & 114.39 & 95.65 \\
\hline $\mathrm{BIC}$ & 195.89 & 172.47 & 158.19 & 133.84 \\
\hline
\end{tabular}

Source: authors' calculations.

a Dependent variable: fraction of firms that change prices at least four times a year.

${ }^{b} p$-values: ${ }^{*}=p<.1 ;{ }^{\star *}=p<.05 ;{ }^{* \star *}=p<.01$. Computed using Huber-White robust standard errors.

c Definition of explanatory variables: see the main text. The reference industry is Food in Portugal.

d The Luxembourg survey does not include any manufacturing industry in which more than ten firms were surveyed. An alternative measure of competition is obtained using the percentage of firms that employ markup rules. The main disadvantage of this measure is that it is not available for Austria and Luxembourg. Column 1 of Table 6 reports the results for the full sample. It is found that competition, costs and demand variables are all significant. This result also holds for the smaller sample of highly representative industries (column 2). Considering only manufacturing firms does not change results (column 3 ) and these are also robust to the use of the high representative sample (column 4). 
Determinants of price flexibilitya,b (markup specification excluding product market regulation)

\begin{tabular}{|c|c|c|c|c|}
\hline \multirow[t]{2}{*}{ Explanatory variables ${ }^{c}$} & \multicolumn{2}{|c|}{ Manufacturing and services } & \multicolumn{2}{|c|}{ Manufacturing } \\
\hline & Full sample & $\begin{array}{l}\text { High } \\
\text { representativity } \\
\text { sample }\end{array}$ & Full sample & $\begin{array}{l}\text { High } \\
\text { representativity } \\
\text { sample }\end{array}$ \\
\hline Markup & $-0.02^{\star \star \star}$ & $-0.02^{\star \star \star}$ & $-0.02^{\star \star \star}$ & $-0.02^{\star \star}$ \\
\hline Labor & $-0.33^{*}$ & $-0.39^{\star \star}$ & $-0.42^{\star \star}$ & $-0.47^{\star \star}$ \\
\hline Raw materials & $0.37^{\star \star}$ & $0.41^{\star \star *}$ & $0.45^{\star \star \star}$ & $0.48^{* * *}$ \\
\hline Demand & $0.32^{*}$ & $0.52^{\star \star \star}$ & $0.32^{\star}$ & $0.47^{\star \star \star}$ \\
\hline Belgium & -0.11 & -0.15 & 0.04 & 0.16 \\
\hline France & -0.32 & -0.27 & -0.47 & -0.33 \\
\hline Germany & $1.13^{\star \star \star}$ & $1.00^{\star \star}$ & $1.05^{\star \star}$ & $0.86^{\star \star}$ \\
\hline Italy & -0.27 & -0.56 & -0.33 & $-0.87^{\star}$ \\
\hline The Netherlands & $0.83^{\star}$ & 0.38 & - & - \\
\hline Spain & -0.01 & -0.12 & -0.27 & -0.28 \\
\hline Consumer non food goods & $-0.83^{\star \star}$ & $-0.76^{\star \star}$ & $-0.75^{\star \star}$ & $-0.72^{\star \star}$ \\
\hline Intermediate goods & -0.47 & $-0.64^{\star \star}$ & -0.48 & $-0.63^{\star \star}$ \\
\hline Capital goods & $-0.85^{\star \star}$ & $-0.85^{\star *}$ & $-0.81^{\star *}$ & $-0.79^{\star \star}$ \\
\hline Trade & -0.19 & 0.26 & - & - \\
\hline Hotels and restaurants & $-0.79^{*}$ & -0.57 & - & - \\
\hline Transport and communications & $-1.45^{\star \star \star}$ & $-1.62^{\star \star \star}$ & - & - \\
\hline Constant & -2.6 & $-3.50^{\star \star}$ & -2.41 & $-3.41^{\star *}$ \\
\hline Number of obs. & 122 & 108 & 104 & 93 \\
\hline Pseudo R squared & 0.36 & 0.33 & 0.40 & 0.33 \\
\hline Log likelihood & -31.42 & -27.46 & -26.43 & -23.46 \\
\hline AlC & 96.84 & 88.92 & 78.87 & 72.92 \\
\hline $\mathrm{BIC}$ & 144.51 & 134.51 & 113.24 & 105.84 \\
\hline
\end{tabular}

Source: authors' calculations.

a Dependent variable: fraction of firms that change prices at least four times per year.

b $p$ values: ${ }^{*}=p<.1 ;{ }^{* *}=p<.05 ;{ }^{* * *}=p<.01$. Computed using Huber-White robust standard errors.

c Definition of explanatory variables: see the main text. The reference industry is Food in Portugal. Table 7 considers the addition of either objective or subjective measures of product market regulation to the specifications in Table 6. Column 1 includes the objective measure of Nicoletti et al. (1999) for the whole sample of manufacturing and services industries. It is found that competition, cost structure and demand variables are highly significant. Moreover, those countries in which product market regulation is more important display a lower degree of price flexibility. Column 2 reports results using the subjective measure by Pryor (2002) and shows that the results are robust to the change in the regulation variable. As an additional check, we consider just manufacturing sectors. The relevance of competition, cost structure and demand variables are again found, regardless of the use of an objective (column 3) or subjective (column 4) measure of product market regulation. 
Determinants of price flexibilitya,b (markup specification including product market regulation)

\begin{tabular}{|c|c|c|c|c|}
\hline \multirow{2}{*}{ Explanatory variables ${ }^{c}$} & \multicolumn{2}{|c|}{ Manufacturing and services } & \multicolumn{2}{|c|}{ Manufacturing } \\
\hline & $\begin{array}{l}\text { Objective } \\
\text { regulationd }^{d}\end{array}$ & $\begin{array}{l}\text { Subjective } \\
\text { regulatione }\end{array}$ & $\begin{array}{l}\text { Objective } \\
\text { regulation }^{\text {d }}\end{array}$ & $\begin{array}{l}\text { Subjective } \\
\text { regulatione }\end{array}$ \\
\hline Markup & $-0.02^{\star \star}$ & $-0.02^{\star \star \star}$ & $-0.02^{\star \star}$ & $-0.02^{\star \star \star}$ \\
\hline Labor & $-0.45^{\star \star \star}$ & $-0.37^{\star \star \star}$ & $-0.51^{\star \star \star}$ & $-0.37^{\star \star \star}$ \\
\hline Raw materials & $0.40^{\star \star \star}$ & $0.41^{\star \star \star}$ & $0.48^{\star \star}$ & $0.43^{\star *}$ \\
\hline Demand & $0.32^{\star *}$ & $0.33^{\star \star}$ & $0.32^{*}$ & $0.35^{\star *}$ \\
\hline Product markets regulation & $-2.51^{\star \star \star}$ & $-2.45^{\star \star \star}$ & $-2.48^{\star \star \star}$ & $-2.79^{\star \star \star}$ \\
\hline Consumer non food goods & $-0.75^{\star \star}$ & $-0.81^{\star *}$ & $-0.72^{\star \star}$ & $-0.81^{\star \star}$ \\
\hline Intermediate goods & -0.45 & $-0.48^{*}$ & $-0.46^{*}$ & $-0.51^{*}$ \\
\hline Capital goods & $-0.76^{\star \star}$ & $-0.82^{\star \star}$ & $-0.73^{\star \star}$ & $-0.85^{\star \star}$ \\
\hline Trade & -0.17 & -0.34 & - & - \\
\hline Hotels and restaurants & $-0.79^{\star}$ & $-1.14^{\star \star \star}$ & - & - \\
\hline Transport and communications & $-1.39^{\star \star \star}$ & $-1.52^{\star \star \star}$ & - & - \\
\hline Constant & -0.49 & -1.03 & -0.64 & -0.85 \\
\hline Number of obs. & 122 & 122 & 104 & 104 \\
\hline Pseudo R squared & 0.30 & 0.34 & 0.31 & 0.35 \\
\hline Log likelihood & -31.96 & -31.64 & -27.06 & -26.73 \\
\hline AIC & 87.92 & 87.28 & 72.11 & 71.45 \\
\hline $\mathrm{BIC}$ & 121.57 & 120.93 & 95.91 & 95.25 \\
\hline
\end{tabular}

Source: authors' calculations.

a Dependent variable: fraction of firms that change prices at least four times a year.

b $p$ values: ${ }^{*}=\mathrm{p}<.1 ;{ }^{* \star}=\mathrm{p}<.05 ;{ }^{* \star}=\mathrm{p}<.01$. Computed using Huber-White robust standard errors.

$c$ Definition of explanatory variables: see the main text. The reference industry is Food in Portugal.

d Objective product market regulation variable. Source: Nicoletti et al. (1999).

e Subjective product market regulation variable. Source: Pryor (2002). 
Conclusions

Recent empirical studies on price setting behavior using micro data have shown a marked heterogeneity in the degree of price stickiness across industries. In this paper, we have explored the role of a number of factors in explaining this heterogeneity, on the basis of the information provided by surveys on pricing behavior conducted in nine euro area countries. The main focus has been placed on the influence of the intensity of competition on the degree of price flexibility. Our results suggest that the pricing policies of firms operating in more competitive environments show greater flexibility in certain aspects. These firms carry out price revisions and changes substantially more often and tend to use markup rules to a lesser extent. Overall, the price setting strategies of the most competitive firms give them a greater capacity to react to shocks and make, in practice, for greater flexibility in their prices.

The direct influence of market competition on price flexibility is corroborated by a cross-country cross-industry econometric analysis based on the information provided by the surveys. This analysis also shows that the cost structure and demand conditions help to explain the degree of price flexibility. Finally, it suggests that countries in which product market regulation is more relevant are characterized by less price flexibility. Overall, these results are in line with the micro quantitative evidence on the determinants of the frequency of consumer and producer price changes [Sabbatini et al. (2006)]. 


\section{REFERENCES}

ÁLVAREZ, L. J., P. BURRIEL and I. HERNANDO (2005). Price setting behaviour in Spain: evidence from micro PPI data. Banco de España Working Paper No. 0527.

ÁLVAREZ, L., and I. HERNANDO. (2005). The Price Setting Behaviour of Spanish Firms: Evidence from Survey Data. Banco de España Working Paper No. 0537.

AUCREMANNE, L., and M. DRUANT. 2005. Price-Setting Behaviour in Belgium: What Can Be Learned from an Ad Hoc Survey? ECB Working Paper No. 448.

BEDROSSIAN, A., and D. MOSCHOS (1988). "Industrial structure, concentration and the speed of price adjustment", Journal of Industrial Economics, 36, pp. 459-475.

BLINDER, A. S., ELIE R. D. CANETTI, D. E. LEBOW and J. B. RUDD (1998). Asking about prices: A new approach to understand price stickines, New York: Russel Sage Foundation.

BRESNAHAN, T. F. (1989). "Empirical studies of industries with market power", in Handbook of Industrial Economics, R. Schmalensee and R. Willig (eds.), Amsterdam: North-Holland.

CARLTON, D. W. (1986). "The rigidity of prices", American Economic Review, 76, pp. 637-658.

- (1989). "The theory and facts about how markets clear", in Handbook of Industrial Economics, R. Schmalensee and R. Willig (eds.), Amsterdam: North-Holland.

CORNILLE, D., and M. DOSSCHE (2006). The patterns and determinants of price setting in the Belgian industry, mimeo, National Bank of Belgium.

DIXON, R. (1983). "Industry structure and the speed of price-adjustment", Journal of Industrial Economics, 31, pp. 25-37.

DOMBERGER, S. (1979). "Price adjustment and market structure", The Economic Journal, 89, pp. 96-108.

EICHNER, A. S. (1973). "A theory of the markup under oligopoly", The Economic Journal, 83, pp. 1184-1200.

ENCAOUA, D., and P. A. GEROSKI (1986). "Price dynamics and competition in five OECD countries", OECD EConomic Studies, 6, pp. 47-76.

FABIANI, S., M. DRUANT, I. HERNANDO, C. KWAPIL, B. LANDAU, C. LOUPIAS, F. MARTINS, T. MATHÄ, R. SABBATINI and A. STOKMAN (2006). "The pricing behaviour of firms in the Euro Area: new survey evidence", International Journal of Central Banking 2(3) 3-47.

GEROSKI, P. (1992). "Price dynamics in UK manufacturing: a microeconomic view", Economica, 59, pp. 403-419.

GINSBURGH, V., and P. MICHEL (1988). "Adjustment costs, concentration, and price behavior", Journal of Industrial Economics, 36, pp. 477-481.

HALL, S., M. WALSH and A. YATES (2000). "How Do UK Companies Set Prices", Oxford Economic Papers, 52, pp. 425-446.

HOEBERICHTS, M., and A. STOKMAN (2006). Pricing behaviour of Dutch companies: main results from a survey, ECB Working Paper No. 607

LÜNNEMANN, P., and T. MATHÄ (2005). Consumer Price Behaviour in Luxembourg: Evidence From Micro CPI data, ECB Working Paper No. 541.

MARTIN, C. (1993). "Price adjustment and market structure", Economics Letters, 41, pp. 139-143.

MEANS, G. C. (1935). "Notes on inflexible prices", American Economic Review, 26, pp. 23-35.

MILLS, F. C. (1927). The behavior of prices, National Bureau of Economic Research, New York.

NICOLETTI, G., and F. L. PRYOR (2006). "Subjective and objective measures of governmental regulations in OECD nations", Journal of Economic Behavior and Organization, 59, pp. 433-449.

NICOLETTI, G, S. SCARPETTA and O. BOYLAUD (1999). Summary Indicators of Product Market Regulation with an Extension to Employment Protection Legislation, OECD Economics Department Working Papers No. 226, Paris: OECD.

PAPKE, L. E., and J. M. WOOLRIDGE (1996). "Econometric Methods for Fractional Response with an Application to 401(K) Plan Participation Rates", Journal of Applied Econometrics, 11, pp. 619-632.

PRYOR, F. L. (2002). "Quantitative notes on the extent of governmental regulations in various OECD nations", International Journal of Industrial Organization, 20, pp. 693-715.

SABBATINI, R., L. J. ÁlVAREZ, E. DHYNE, M. HOEBERICHTS, H. LE BIHAN, P. LÜNNEMANN, F. MARTINS, F. RUMLER, H. STAHL, P. VERMEULEN, G. VERONESE, and J. VILMUNEN (2006) What Quantitative Micro Data Reveal about Price Setting Behavior in S. FABIANI, C. LOUPIAS, F. MARTINS, and R. SABBATINI (eds.) Pricing Decisions in the Euro Area: How Firms Set Prices and Why. Oxford University Press.

SILBERSTON, A. (1970). "Surveys of applied economics: Price behaviour of firms", The Economic Journal, 80, pp. 511-582.

STIGLER, G. S. (1964). "A theory of oligopoly", Journal of Political Economy, 72, pp. 44-61.

STIGLITZ, J. E. (1984). "Price rigidities and market structure", American Economic Review, 74, pp. 350-355.

WEISS, C. R. (1995). "Determinants of price flexibility in oligopolistic markets: evidence from Austrian manufacturing firms", Journal of Economics and Business, 47, pp. 423-439. 
BANCO DE ESPAÑA PUBLICATIONS

\section{WORKING PAPERS ${ }^{1}$}

0527 LUIS J. ÁLVAREZ, PABLO BURRIEL AND IGNACIO HERNANDO: Price setting behaviour in Spain: evidence from micro PPI data.

0528 EMMANUEL DHYNE, LUIS J. ÁLVAREZ, HERVÉ LE BIHAN, GIOVANNI VERONESE, DANIEL DIAS, JOHANNES HOFFMANN, NICOLE JONKER, PATRICK LÜNNEMANN, FABIO RUMLER AND JOUKO VILMUNEN: Price setting in the euro area: some stylized facts from individual consumer price data.

0529 TERESA SASTRE AND JOSÉ LUIS FERNÁNDEZ-SÁNCHEZ: Un modelo empírico de las decisiones de gasto de las familias españolas.

0530 ALFREDO MARTÍN-OLIVER, VICENTE SALAS-FUMÁS AND JESÚS SAURINA: A test of the law of one price in retail banking.

0531 GABRIEL JIMÉNEZ AND JESÚS SAURINA: Credit cycles, credit risk, and prudential regulation.

0532 BEATRIZ DE-BLAS-PÉREZ: Exchange rate dynamics in economies with portfolio rigidities.

0533 ÓSCAR J. ARCE: Reflections on fiscalist divergent price-paths.

0534 M. ${ }^{a}$ DE LOS LLANOS MATEA AND MIGUEL PÉREZ: Differences in changes in fresh food prices by type of establishment. (The Spanish original of this publication has the same number.)

0535 JOSÉ MANUEL MARQUÉS, FERNANDO NIETO AND ANA DEL RíO: Una aproximación a los determinantes de la financiación de las sociedades no financieras en España.

0536 S. FABIANI, M. DRUANT, I. HERNANDO, C. KWAPIL, B. LANDAU, C. LOUPIAS, F. MARTINS, T. MATHÄ, R. SABBATINI, H. STAHL AND A. STOKMAN: The pricing behaviour of firms in the euro area: new survey evidence.

0537 LUIS J. ÁLVAREZ AND I. HERNANDO: The price setting behaviour of Spanish firms: evidence from survey data.

0538 JOSÉ MANUEL CAMPA, LINDA S. GOLDBERG AND JOSÉ M. GONZÁLEZ-MíNGUEZ: Exchange-rate pass-through to import prices in the euro area.

0539 RAQUEL LAGO-GONZÁLEZ AND VICENTE SALAS-FUMÁS: Market power and bank interest rate adjustments.

0540 FERNANDO RESTOY AND ROSA RODRÍGUEZ: Can fundamentals explain cross-country correlations of asset returns?

0541 FRANCISCO ALONSO AND ROBERTO BLANCO: Is the volatility of the EONIA transmitted to longer-term euro money market interest rates?

0542 LUIS J. ÁLVAREZ, EMMANUEL DHYNE, MARCO M. HOEBERICHTS, CLAUDIA KWAPIL, HERVÉ LE BIHAN, PATRICK LÜNNEMANN, FERNANDO MARTINS, ROBERTO SABBATINI, HARALD STAHL, PHILIP VERMEULEN AND JOUKO VILMUNEN: Sticky prices in the euro area: a summary of new micro evidence.

0601 ARTURO GALINDO, ALEJANDRO IZQUIERDO AND JOSÉ MANUEL MONTERO: Real exchange rates, dollarization and industrial employment in Latin America.

0602 JUAN A. ROJAS AND CARLOS URRUTIA: Social security reform with uninsurable income risk and endogenous borrowing constraints.

0603 CRISTINA BARCELÓ: Housing tenure and labour mobility: a comparison across European countries.

0604 FRANCISCO DE CASTRO AND PABLO HERNÁNDEZ DE COS: The economic effects of exogenous fiscal shocks in Spain: a SVAR approach.

0605 RICARDO GIMENO AND CARMEN MARTÍNEZ-CARRASCAL: The interaction between house prices and loans for house purchase. The Spanish case.

0606 JAVIER DELGADO, VICENTE SALAS AND JESÚS SAURINA: The joint size and ownership specialization in banks' lending.

0607 ÓSCAR J. ARCE: Speculative hyperinflations: When can we rule them out?

0608 PALOMA LÓPEZ-GARCÍA AND SERGIO PUENTE: Business demography in Spain: determinants of firm survival.

0609 JUAN AYUSO AND FERNANDO RESTOY: House prices and rents in Spain: Does the discount factor matter?

0610 ÓSCAR J. ARCE AND J. DAVID LÓPEZ-SALIDO: House prices, rents, and interest rates under collateral constraints.

0611 ENRIQUE ALBEROLA AND JOSÉ MANUEL MONTERO: Debt sustainability and procyclical fiscal policies in Latin America.

1. Previously published Working Papers are listed in the Banco de España publications calalogue. 
0612 GABRIEL JIMÉNEZ, VICENTE SALAS AND JESÚS SAURINA: Credit market competition, collateral and firms' finance.

0613 ÁNGEL GAVILÁN: Wage inequality, segregation by skill and the price of capital in an assignment model.

0614 DANIEL PÉREZ, VICENTE SALAS AND JESÚS SAURINA: Earnings and capital management in alternative loan loss provision regulatory regimes.

0615 MARIO IZQUIERDO AND AITOR LACUESTA: Wage inequality in Spain: Recent developments.

0616 K. C. FUNG, ALICIA GARCÍA-HERRERO, HITOMI IIZAKA AND ALAN SUI: Hard or soft? Institutional reforms and infraestructure spending as determinants of foreign direct investment in China.

0617 JAVIER DÍAZ-CASSOU, ALICIA GARCÍA-HERRERO AND LUIS MOLINA: What kind of capital flows does the IMF catalyze and when?

0618 SERGIO PUENTE: Dynamic stability in repeated games.

0619 FEDERICO RAVENNA: Vector autoregressions and reduced form representations of DSGE models.

0620 AITOR LACUESTA: Emigration and human capital: Who leaves, who comes back and what difference does it make?

0621 ENRIQUE ALBEROLA AND RODRIGO CÉSAR SALVADO: Banks, remittances and financial deepening in receiving countries. A model.

0622 SONIA RUANO-PARDO AND VICENTE SALAS-FUMÁS: Morosidad de la deuda empresarial bancaria en España, 1992-2003. Modelos de la probabilidad de entrar en mora, del volumen de deuda en mora y del total de deuda bancaria, a partir de datos individuales de empresa.

0623 JUAN AYUSO AND JORGE MARTíNEZ: Assessing banking competition: an application to the Spanish market for (quality-changing) deposits.

0624 IGNACIO HERNANDO AND MARÍA J. NIETO: Is the Internet delivery channel changing banks' performance? The case of Spanish banks.

0625 JUAN F. JIMENO, ESTHER MORAL AND LORENA SAIZ: Structural breaks in labor productivity growth: The United States vs. the European Union.

0626 CRISTINA BARCELÓ: A Q-model of labour demand.

0627 JOSEP M. VILARRUBIA: Neighborhood effects in economic growth.

0628 NUNO MARTINS AND ERNESTO VILLANUEVA: Does limited access to mortgage debt explain why young adults live with their parents?

0629 LUIS J. ÁLVAREZ AND IGNACIO HERNANDO: Competition and price adjustment in the euro area. 


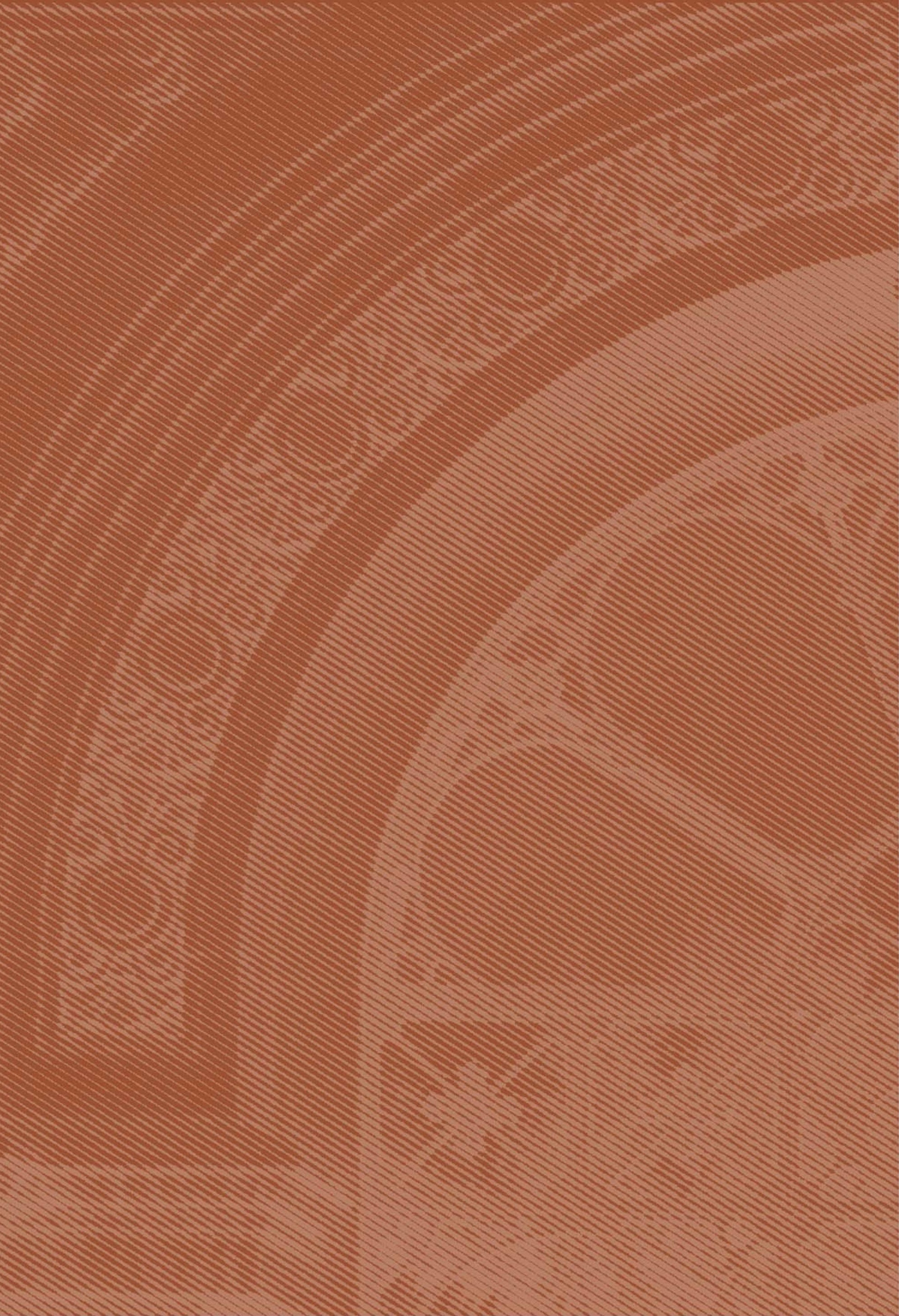

